\title{
Degree of Competency in Practicing Basic Education for Kindergarten Teachers from the Point of View of the Teachers Themselves
}

\author{
Dr. Fatima Ahmed Abu Hamda \\ Department of Curriculum and Teaching \\ University of Islamic Sciences, Jordan
}

Doi: 10.19044/esj.2018.v14n10p136 URL:http://dx.doi.org/10.19044/esj.2018.v14n10p136

\begin{abstract}
The study aimed to identify the degree of practicing the basic educational competencies of kindergarten teachers from the point of view of the teachers themselves. The study sample consisted of 125 randomly selected teachers. The researcher used the questionnaire as a tool of study consisting of 50 paragraphs divided into five areas (personal competencies, competencies for the management of the classroom and interaction with children, competencies of teaching skills, educational competencies for human relations, and the field of professional growth). After the statistical analysis was performed, the study reached the following results: There were statistically significant differences at $\alpha \leq 0.05$ between the bachelor degree on the one hand and the diploma and postgraduate studies on the other hand. The differences were in favor of Bachelor of personal competencies. Also, there is the existence of statistical significant difference $(\alpha \leq 0.05)$ between 10 years and more and 5-10 years. This difference is based on the benefit of 10 years and more educational competencies for the field of human relations. The researcher recommended that training courses should be organized as this would contribute to increasing the efficiency and skills of kindergarten teachers.
\end{abstract}

Keywords: Educational competencies, Kindergarten teachers, teaching skills

\section{Introduction}

Childhood is one of the most important stages in human life, in which the characteristics of personality are determined and are more susceptible to the different factors and circumstances surrounding it. Therefore, attention has been given to childhood as it is the best stage of education and in gaining experience. This, however, would help children to achieve better learning at 
different stages of education. It is an educational stage necessary to pave the way for subsequent educational process. Also, it is the strong bridge to bring children from the family atmosphere to the atmosphere of the school.

In the 21 st century, attention to early childhood has become one of the priorities of the educational goals at the international and Arab levels (Abu Harb, 2005). Therefore, the educational programs is focused on preparing the children's teacher and providing them with the necessary skills needed to deal with knowledge on the one hand and with children on the other hand. Colleges and universities are concerned with the preparation of pre-school teachers in the design of educational programs according to the competencies and skills. However, this is based on the fact that teachers will use these skills and competencies to develop the abilities of children in the course of their education (Quebec, 2002).

There is no doubt that the distinguished teacher should possess the basic educational competencies that enable her to help children adapt to society, prepare them to overcome the difficulties of the environment around them, and develop their abilities to deal with the world's rapid variables; hence, this is in addition to their role in the preparation of academic and for formal education in the school (Mardan, Sharif \& Abdel-Al, 2004).

Holly and Gohar (2004) pointed out that the method developed in the educational process of kindergarten teachers is based on the thought, breeding, and planning of the program by the parameter, freedom and play, selection, discovery, experimentation, and self-learning by the child. This is performed based on an approach that is flexible enough to meet the individual needs of children and based on a plan of action to introduce concepts, knowledge, and skills that the child learns through play and discovery rather than to teach the child. It also entails an organized and encouraging learning environment that gives the child freedom of movement, selection, experimentation, and discovery. Furthermore, educational tools and games that stimulate the child's spontaneity, makes him to enjoy his freedom. It also motivates him to imagine, discover, and investigate.

Al-Hooli (2001) also pointed out that the method developed in the educational process of kindergarten teachers is based on providing an area of interaction and communication between the child and the other children, between the child and the teacher, and between the child and his peers. Thus, this encourages the child to be independent, self-confidence, and possess respect. To develop self-confidence, the courage to think in a different, renewed, and complex manner is required. Also, a close relationship exists between kindergarten and the home so as to provide parents with information on how to stimulate children's thinking to make the most of this relationship.

In view of the importance of this stage and its obvious impact on the growth of children in all aspects, the teacher's attention was first and second 
parameter for these children. Therefore, the prevailing trend is that kindergartens are qualified teachers without teachers. Women are closer to men based on nature. At the early stage of childhood, it is important to be closer to the man so as to understand him. Therefore, it is more natural to know the most appropriate way to deal with him not far from the atmosphere he made at home. Thus, women generally have love for children and their ability to accept them. The most important elements to take on this task is the need to know the psychology of childhood in a way that enables them to identify children and know their needs and tendencies so as to work to meet and satisfy them (Mardan et al., 2004).

The kindergarten teacher is the backbone and he/she plays a central role in achieving sound education with its capabilities and creative potential and the ability to discover the child and his inner energies. The programs of kindergartens and daily activities and educational goals cannot be accomplished except by the specialized teacher awareness of the requirements of early childhood and its basic needs for the role of education in kindergarten. Thus, this requires that we stop in front of what the teacher knows about the method developed, how to work, implementation, and the degree of ownership and exercise of educational competencies necessary to achieve the goals of the educational process of kindergarten. Hence, this is exactly what this study is trying to research.

\section{Study Problem and Questions}

The problem of the study emerged through the researcher's perception that the educational competencies of kindergarten teachers are low, through her personal observations that she has been the director of a private school for decades, and also through her meetings with the teachers of the kindergarten stage. However, this prompted the researcher to study the educational competencies that must be available to kindergarten teachers. It has also helped them to raise the degree of exercise of the basic educational competencies due to the stage of the impact on the development of the child's development which is comprehensive and balanced. From the perspective of the researcher, the role of kindergartens is not limited to the development of the child's skills and preparation for a larger society; rather, it has an important educational role, such as that of the school. Also, it is concerned with building a good citizen that builds a strong young nation in the future.

Therefore, this study aims to reveal the importance of some of the basic educational competencies from the point of view of teachers and their practice of these competencies by answering the main question:

What is the degree of practice of the basic educational competencies of the kindergarten teachers from the point of view of the teachers themselves? 
From the above question, the following sub-questions was drawn: - Are there any statistically significant differences at the level of $(\alpha \leq 0.05$ the exercise of the basic educational competencies of the kindergarten teachers from the point of view of the teachers themselves due to the variable of the training course?

- Are there any statistically significant differences at the level of $(\alpha \leq 0.05)$ exercise of the basic educational competencies of kindergarten teachers from the point of view of the teachers themselves due to the variable of experience? - Are there any statistically significant differences at the level of $(\alpha \leq 0.05)$ the exercise of the basic educational competencies of the kindergarten teachers from the point of view of the teachers themselves due to the variable of the scientific qualification?

\section{The Importance of the Study}

The importance of this study came from two aspects:

The theoretical importance of this study which is summarized based on the importance of preparing kindergartens teachers and raising the degree of their practice of basic educational competencies. The importance of this study also stems from the need to discuss the subject of the expected benefit added by the results of scientific knowledge in this area, and the importance of educational competencies and the need to acquire each of them. Given the special nature of this important age of the child's life, and the developmental, social and skill requirements that the teacher seeks to satisfy the child at this stage, only a qualified and well prepared teacher should teach the children. They have to be well prepared professionally and academically in order to meet all the requirements and satisfy the basic needs of pre-school children.

The Practical Importance: This study may provide a frame of reference and an introduction to future research and studies in the field of educational competencies of kindergarten teachers, as well as opening up the possibility for other researchers in the future to take care of this subject and study it in other aspects. The study provides a tool that can be used in future studies. Thus, this is in addition to providing quantitative data and information about the nature of the relationship between the variables of the study. It also provides a theoretical framework of concepts, data, and information. This study should be a scientific study in addition to the Arabic library in general and to the Jordanian library in particular.

\section{Procedural Definitions}

Competencies: Competencies are defined as a set of information, experiences, skills, activities, and behavior patterns that kindergarten teachers possess, which teachers are supposed to exercise during the pre-school 
educational process and measured to the degree obtained by the examinee on the scale prepared for the purposes of this study.

Kindergarten: It is defined as an educational institution licensed by the Ministry of Education according to certain specifications. It is responsible for the development of the abilities of children in the age group 3-5 years in order to achieve growth, physical, mental, psychological, emotional, and social development.

Kindergarten Teacher: It is defined as an educational figure chosen very carefully through a set of special standards and physical, mental, social, ethical and emotional characteristics that is appropriate for the child education profession, and has received preparation and integrated training in university colleges to take responsibility of educational work in pre-school institutions.

\section{The Limitation of the Study}

The current study is limited to the following limits:

Spatial Boundaries: Riyad Private Education, in the Capital Governorate of Amman, Jordan.

Time Limits: During the academic year 2017/2018.

Human Boundaries: Private kindergarten teachers in private education (125).

\section{Theoretical Framework and Previous Studies Theoretical Framework}

Educational Competencies: This can be defined as a set of abilities and skills possessed by the teacher, which enables him to perform his duties and roles and responsibilities to the best of his performance. However, this is reflected on the educational process as a whole, especially in terms of success and ability of the teacher to transfer information to students. The teacher may do so through planning and preparation of the lesson, and through other daily and applied teaching activities, which are evident in the behavior and educational preparation of the teacher within and outside the classroom (Karam, 2002).

The trend of educational competencies is one of the most recent trends in teacher education and training programs over the last three decades. Many educators have adopted enough knowledge in teacher education programs. They have started in American society as a cultural movement in which the teacher's performance is evaluated through the behavior of the learner. However, the attention shifted to the evaluation of the teacher through the programs of preparation and training, which was based on strengthening the educational and psychological foundations. This trend has spread in the form of a large movement known as the movement of teachers on the basis of competencies. In addition, it is based on the idea that the competent teacher is the one who possesses a set of competencies capable of performing tasks 
related to his different roles, and performing them with a certain level of ability to perform (Holly, Jawhar \& Al-Qallaf, 2007).

Consequently, the importance of educational competencies in the preparation of teachers has touched a lot of educational researchers. Karam (2002) defined educational competencies as the ability of the teacher to perform a specific behavior related to his or her teaching tasks, and consists of specific knowledge, skills, attitudes and values directly related to teaching, expressed in his or her words and actions and performed with an appropriate degree of proficiency for the purpose of achieving the desired result. Murtada (2001) defined it as the ability of the teacher to perform a work or behavior in the educational situation, whether this work or behavior is cognitive or physical, or performance has an appropriate degree of perfection to connect to the desired results and to point less.

In the course of the competencies of the kindergarten teacher in the various studies and literature examined by the researcher, some of the basic competencies were chosen in an attempt to include all the main aspects required by the kindergarten teacher to be included here in the theoretical framework. In this section of the study tool, the researcher found the following classification of competencies:

- Personal competencies.

- Competencies in the management of separation and interaction with children.

- Skills of teaching skills.

- Educational competencies for the field of human relations.

\section{- Professional growth competencies.}

Here, each subset of sub-competencies is formulated in the form of acts of prescriptions and practices required in the kindergarten teacher.

Personal Competencies: The level of performance of the kindergarten teacher based on the characteristics. The most important personal competencies mentioned in the research and literature was as follows (Karrar, 2000):

- They should be committed to ethics to be a role model to the children, enjoy patience, be calm, and emotionally stable.

- They should have the ability to understand others and to deal with children.

- They should be intelligent and to be always present.

- They should be sound physically and have the fitness to allow movement and activity to follow activities, in addition to be free of infectious diseases for the safety of the child.

- They should take care of their appearance and ensure the simplicity of their clothing, in order to become an example to the children and attract them in the beauty of their appearance and simplicity. 
The competencies of the Department of Separation and Interaction with Children: It means the skills of communication with children and interaction with them and their leadership. It also refers to the ability to control their behavior in the classroom without notice that they are restricted, and make them want to be in class and with the teacher on their own. Thus, the most important of these competencies include:

- Provide opportunities for children to form social relationships with their peers in kindergarten.

- Provide opportunities for each child to be able to express himself and his potential.

- Seeks to affirm the spirit of the group and the dissemination of cooperative work among children through the creation of means together or by arranging the classroom, hygiene, or collective games and so on.

- Create an atmosphere of tranquility and fun in the learning environment using the songs and games that separate the experience and the use of attractive colors that are comfortable.

- Communicate effectively with children verbally by creating an individual dialogue or by listening to them with interest, and communicating nonverbally by looking at the child, raising, embracing, smiling, and through other means of communication.

Skills of Teaching: This has to do with the reality of the actual level of performance of the kindergarten teacher and their skills in the classroom, through which the teacher can attract the child's educational attention and respond to the different experiences and activities in order to transfer the aspects of knowledge that the child needs in light of the stage. Thus, these include:

- Participation of children in the selection of topics of activity to ensure their interaction with them and their attention.

- Create an atmosphere of love and familiarity.

- Diversity of educational attitudes in a way that motivates children's motivation to learn.

- Organizing the educational environment in a way that motivates children to learn.

- Positive reinforcement of non-traditional children's responses is used and admiration is expressed for their innovations.

Educational Competencies for the Field of Human Relationship: This refers to the skills of interaction with others and with children and the establishment of social relations that enrich the process of education, and the ability to agree with others. The most important of them include (Sulaimani, 2006):

- To strengthen the religious spirit in children.

- To interact with the families of children in their visits to kindergarten. 
- To establish positive relationships with colleagues at work.

- Interacts with the problems of children and work to help them in their participation and also emotionally.

- To enjoy the children for a long time and make them feel that they are the focus of attention.

The Competencies of Professional Growth: These competencies indicate the ability of the teacher to perform the tasks of education with a high level of proficiency with the skills of self-development and motivation for development and keeping abreast of developments in the field of education. Thus, the most important of which are: (Mr., 2013):

- Being fluent in Arabic reading and writing and proper use. - Keep abreast of emerging information concerning the characteristics of children's growth.

- Always wish to innovate and renew continuous educational programs.

- Appropriate tools (observation, interview, scales) should be used in children's assessment and identification.

- Diversity in teaching and learning methods that helps to overcome the boredom that afflicts or affects children.

The researcher believes that the success of the teacher in her work depends not only on the availability of her competencies, but must succeed in harnessing these competencies and using them all effectively. Thus, this can be achieved with the help of the strength of her faith in her educational mission and the awakening of her conscience and the strength of her will and determination. This is in addition to the strength of her motivation and her desire towards her profession.

\section{Previous Studies}

The Kiesner study (2008) aimed to identify ways to develop teacher preparation programs and increase their educational competencies at the University of Pennsylvania in the light of contemporary trends in early childhood education. The study sample consisted of 322 teachers, 14 university teachers, and 4 faculty members. The researcher used the questionnaire as a study material, which was divided into several dimensions. The study reached a number of results. The most important of these results are the insufficient period of practical application of the teaching profession and providing the necessary skills for teaching, Increased follow-up, and observation. During its application in kindergartens, teachers were able to focus on feedback to educational situations, and to increase collaboration between university supervisors and teachers in the assessment process.

Al-Muzayen and Gharab (2005) studied the aim of determining the most basic competencies of kindergarten teachers in Gaza Governorate. From the point of view of the directors of Riyadh, the researchers used the 
questionnaire as a tool for collecting data. The questionnaire consisted of 48 competencies divided into four areas: cognitive skills, Emotional and physical competencies, and the field of professional competencies. The questionnaire was applied to 120 managers from Riyadh. The study stated that all competencies received a high percentage: Emotional, mental cognitive competencies.

The study of Yassin (2003) aimed at determining the general basic educational competencies among kindergarten teachers in government kindergartens in Riyadh city, and to ascertain the degree of availability in each parameter of the study sample. The researcher used a note card containing 58 skills, divided into two areas: 78 teachers in 7 government kindergartens in the city of Riyadh. The researcher found the following results: The performance of kindergarten teachers for teaching competencies is weak, and the degree of availability of personal competencies in Kindergartens' parameters are not different in terms of specialization or qualification. Also, the degree of availability of educational competencies among kindergarten teachers is not different according to the years of experience or courses in which the teachers were enrolled.

Selven (2003) conducted a study aimed at identifying the basic performance competencies and their availability in kindergarten teachers in Pennsylvania. The study sample consisted of a group of specialists in the field of teacher training. The researcher prepared a list of competencies and reached a list that included (61) adequacy, divided into seven aspects. The observation card was applied to a sample of 150 teachers of kindergarten teachers in the State. Their competencies were measured using the experimental method and the study reached a number of results. The study also found that there is no relationship between the number of years of work experience in kindergarten, and the availability of basic skills in the performance parameters.

Al-Shibani (2001) conducted a study aimed at identifying the problems facing public and private kindergartens in the Republic of Yemen from the point of view of the Riyadh educators. The researcher used a questionnaire consisting of 75 paragraphs divided into eight fields. The study found the following results: the most important problems are the problems related to the state institutions concerned with the rehabilitation of nannies. The eight areas differed in the order in terms of the importance of the problems, as follows: The field of state institutions concerned with the rehabilitation of nannies, Equipment field, The field of curriculum and educational activities, financial field, building area, conductors, educational supervision, kindergarten management and organization. However, the games did not show the results of the existence of differences of statistical significance between Riyadh government and eligibility. Also, the researcher recommended the need to 
develop training programs for the rehabilitation of female teachers during the service.

Kemp (2000) studied the aim of identifying the impact of a proposed program based on educational competencies on the development of the skills of kindergarten teachers in Iowa. The sample consisted of 804 teachers divided into two groups. The first group consisted of 453 teachers. In the method of learning based on competencies through a training program designed, the second consisted of 315 teachers learned in the traditional way. The experiment lasted for a full academic year, and it used the researcher interview with the sample four times to know their directions towards their preparation program. Due to the weakness in the teacher preparation program in terms of non-eligibility in teaching, there was no change and significant impact of the theoretical materials that were studied during the year, Hence, the following was considered: the impact of the materials of teaching methods, the emphasis on the theoretical side and the lack of emphasis on the practical side, the time allocated for practical application is inadequate, and insufficient teaching classroom management. This has made the researcher to seek to build an integrated program in terms of objectives, content, methods, teaching aids, and evaluation patterns according to the experimental method.

\section{Method and Procedures}

\section{Study Approach}

In this study, the researcher used the analytical descriptive approach to suit the study.

\section{The Study Sample}

The sample of the study was randomly selected. The sample consisted of 125 female teachers of special education kindergartens in Amman Governorate as shown in Table 1.

Table 1. Frequency and percentages of the study sample by study variables

\begin{tabular}{|c|c|c|c|}
\hline & Categories & Frequency & Percentage \\
\hline \multirow[t]{2}{*}{ Training courses } & yes & 73 & $58.4 \%$ \\
\hline & no & 52 & $41.6 \%$ \\
\hline \multirow[t]{4}{*}{ Work experience } & Less than 5years & 40 & $32 \%$ \\
\hline & From 5 to 10 & 52 & $41.6 \%$ \\
\hline & years & \multirow[t]{2}{*}{53} & \multirow[t]{2}{*}{$26.4 \%$} \\
\hline & $\begin{array}{c}\text { More than } 10 \\
\text { years }\end{array}$ & & \\
\hline \multirow{4}{*}{$\begin{array}{c}\text { Scientific } \\
\text { qualification }\end{array}$} & Diploma & 39 & 31.2 \\
\hline & Bachelor & 54 & 43.2 \\
\hline & Higher studies & 32 & 25.6 \\
\hline & Total & 125 & $100 \%$ \\
\hline
\end{tabular}




\section{Tool Validation}

The credibility of the questionnaire was based on the presentation of a group of arbitrators specialized in the curriculum, methods of teaching, measurement, evaluation, and educational administration of 10 arbitrators. Also, the necessary amendments were recommended by the arbitrators according to their opinions.

\section{Stability of the Study Instrument}

In order to ensure the stability of the study instrument, the test-retest was verified by applying the scale and it was applied after two weeks to a group outside the study sample consisting of 30 parameters. After then, the Pearson correlation coefficient was calculated between their estimates at both times.

The coefficient of consistency was also calculated in the internal consistency method according to the Cronbach alpha equation. Table 2 shows the coefficient of internal consistency according to the Cronbach alpha equation and the regression coefficients for the domains and instrument as a whole.

Table 2. Cronbach alpha consistency coefficient and repeatability of the fields and the total score

\begin{tabular}{|c|c|c|}
\hline The field & Repetition stability & Internal consistency \\
\hline Personal competencies & 0.87 & 0.74 \\
\hline $\begin{array}{c}\text { Competencies in the management of } \\
\text { the class and interaction with children }\end{array}$ & 0.89 & 0.78 \\
\hline Teaching skills competencies & 0.86 & 0.81 \\
\hline $\begin{array}{c}\text { Educational competencies for the field } \\
\text { of human relations }\end{array}$ & 0.87 & 0.79 \\
\hline Professional Growth Competencies & 0.83 & 0.87 \\
\hline Total score & 0.90 & 0.89 \\
\hline
\end{tabular}

\section{Statistical Standard}

The five-dimensional Lycert scale was adopted to correct the study tools by giving each of its paragraphs one of its five degrees (always, often, sometimes, rarely, never). It represents digitally $(5,4,3,2,1)$ respectively. Thus, the following metric was adopted for the purposes of analyzing the results:

From 1.00 to 2.33 low

From 2.34 to 3.67 average

From 3.68 to 5.00 large

And so on

The scale is calculated by using the following equation: 
The upper limit of the scale (5) - The minimum scale (1)

Number of categories required (3)

$5-1=1.33$

3

And then the answer (1.33) is added to the end of each category.

\section{View and Interpret Results}

To answer the first question "What is the degree of the exercise of the basic educational competencies of the kindergarten teachers from the point of view of the teachers themselves?", the arithmetical averages and standard deviations of the degree of exercise of basic educational competencies of kindergarten teachers were extracted from the point of view of the teachers themselves. The table below illustrates this.

Table 3. Mathematical averages and standard deviations of the degree of exercise of the

basic educational competencies of kindergarten teachers from the point of view of the teachers themselves are ranked descending by arithmetic averages

\begin{tabular}{|c|c|c|c|c|c|}
\hline Rank & Number & The field & Average & $\begin{array}{c}\text { Standard } \\
\text { Deviation }\end{array}$ & Degree \\
\hline 1 & 1 & Personal competencies & 4.57 & 0.403 & High \\
\hline 2 & 2 & Teaching skills competencies & 4.50 & 0.395 & High \\
\hline 3 & 3 & $\begin{array}{c}\text { Special competencies Management } \\
\text { of the classroom and interaction with } \\
\text { children }\end{array}$ & 4.41 & 0.379 & High \\
\hline 4 & 4 & $\begin{array}{c}\text { Educational competencies for the } \\
\text { field of human relations }\end{array}$ & 4.41 & 0.444 & High \\
\hline 5 & 5 & Professional Growth Competencies & 4.20 & 0.395 & High \\
\hline & & The total degree & 4.42 & 0.320 & High \\
\hline
\end{tabular}

Table 3 shows that the mathematical averages ranged between 4.204.57, where the personal competencies ranked first with the highest average score of 4.57. This may be attributed to the fact that personal competencies are the first factors affecting the success of kindergarten teacher and so on. The teacher must be characterized by the strength of personality, selfconfidence, intelligence and the presence of intuition, while the competencies of professional growth came in last place with an average of 4.20. This is due to the fact that professional growth needs to keep abreast of development and cooperation with other institutions and the pursuit of innovation. This requires the ability, time, effort and ability to keep abreast of the continuous development and flow of knowledge.

The arithmetical averages and the standard deviations of the estimates of the individuals of the study sample were calculated according to the paragraphs of each field separately, as follows: 


\section{First: Personal Competencies}

Table 4. The arithmetical averages and standard deviations of the paragraphs related to personal competencies are ranked descending by arithmetical averages

\begin{tabular}{|c|c|c|c|c|c|}
\hline Rank & Number & The paragraph & Average & $\begin{array}{c}\text { Standard } \\
\text { Deviation }\end{array}$ & Degree \\
\hline 1 & 4 & $\begin{array}{c}\text { Interested in the appearance and } \\
\text { simplicity of clothing and her } \\
\text { modesty }\end{array}$ & 4.79 & .408 & High \\
\hline 2 & 5 & Healthy, fit and free of diseases & 4.74 & .443 & High \\
\hline 3 & 1 & $\begin{array}{c}\text { Characterized by strong personality } \\
\text { and self-confidence }\end{array}$ & 4.69 & .465 & High \\
\hline 4 & 6 & $\begin{array}{c}\text { Committed to Islamic ethics in word } \\
\text { and deed }\end{array}$ & 4.59 & .597 & High \\
\hline 5 & 3 & $\begin{array}{c}\text { Intelligence, presence of the mind, } \\
\text { and the power of observation }\end{array}$ & 4.54 & .589 & High \\
\hline 5 & 9 & $\begin{array}{c}\text { They are accepted by children and } \\
\text { met with a smiley face }\end{array}$ & 4.54 & .589 & High \\
\hline 5 & 10 & Has a good persuasive ability & 4.51 & .736 & High \\
\hline 8 & 8 & $\begin{array}{c}\text { It has a clear voice tone and a proper } \\
\text { pronunciation of the characters }\end{array}$ & 4.44 & .665 & High \\
\hline 9 & 2 & $\begin{array}{c}\text { Love for knowledge and seek to } \\
\text { develop herself }\end{array}$ & 4. & High \\
\hline 10 & 7 & $\begin{array}{c}\text { Enjoy patience, calmness and } \\
\text { emotional control }\end{array}$ & 4.28 & .779 & High \\
\hline & & Personal competencies & 4.57 & .403 & High \\
\hline
\end{tabular}

Table 4 shows that the arithmetical averages ranged from 4.28-4.79. Paragraph 4, which states that "the appearance and simplicity of clothing and its concentration", is ranked first with an average of 4.79. The appearance contributes to the reassurance of the child and the comfort and love of the teacher and kindergarten. Paragraph 7 which reads "enjoy patience, calm and emotional control" came at the last rank with an average of 4.28. This may be due to the fact that the teacher may suffer from some physical and psychological stress under the current circumstances in addition to the pressures of work and the teaching burden. Thus, this requires effort, time, and ability to adapt and deal with these pressures, leading to the difficulty of emotional control in some cases and the arithmetic average of personal competencies as a whole (4.57). 


\section{Second: Competencies in the Management of Separation and Interaction with Children}

Table 5. The arithmetical averages and standard deviations of paragraphs related to the competencies of classroom management and interaction with children are ranked descending by arithmetical averages

\begin{tabular}{|c|c|c|c|c|c|}
\hline Rank & Number & The paragraph & Average & $\begin{array}{c}\text { Standard } \\
\text { Deviation }\end{array}$ & Degree \\
\hline 1 & 19 & $\begin{array}{l}\text { The child returns to the cleanliness } \\
\text { of the classroom and maintain the } \\
\text { things in it }\end{array}$ & 4.74 & .443 & High \\
\hline 2 & 13 & $\begin{array}{l}\text { Communicate effectively with } \\
\text { children verbally and non verbally by } \\
\text { listening to them, nurturing, } \\
\text { embracing, and through other means } \\
\text { of communication }\end{array}$ & 4.63 & .484 & High \\
\hline 3 & 20 & $\begin{array}{l}\text { Accept the mistakes of children } \\
\text { patiently and do not resort to } \\
\text { punishment from the first mistake, } \\
\text { but gradually alerted } \\
\text { then b Resurrection }\end{array}$ & 4.46 & .501 & High \\
\hline 4 & 11 & $\begin{array}{l}\text { Creating opportunities for children to } \\
\text { form social relationships with their } \\
\text { peers in kindergarten }\end{array}$ & 4.44 & .665 & High \\
\hline 5 & 16 & $\begin{array}{l}\text { Create an atmosphere of tranquility } \\
\text { and fun in the learning environment } \\
\text { using songs, colors and games }\end{array}$ & 4.40 & .793 & High \\
\hline 6 & 15 & $\begin{array}{l}\text { She appreciates imaginative play } \\
\text { and laughs with children and takes } \\
\text { part in the game }\end{array}$ & 4.38 & .657 & High \\
\hline 7 & 14 & $\begin{array}{l}\text { Seeks to affirm the spirit of the } \\
\text { community and the dissemination of } \\
\text { cooperative action among children }\end{array}$ & 4.37 & .666 & High \\
\hline 8 & 12 & $\begin{array}{l}\text { Provide opportunities for each child } \\
\text { to be able to express himself and his } \\
\text { potential }\end{array}$ & 4.32 & .655 & High \\
\hline 9 & 18 & $\begin{array}{l}\text { Allow children to move inside the } \\
\text { classroom without disturbing the } \\
\text { system }\end{array}$ & 4.22 & .682 & High \\
\hline \multirow[t]{2}{*}{10} & 17 & $\begin{array}{l}\text { The reception of each child in the } \\
\text { morning is improved by embracing, } \\
\text { smiling and welcoming }\end{array}$ & 4.17 & .669 & High \\
\hline & & $\begin{array}{l}\text { Competencies in the } \\
\text { management of separation and } \\
\text { interaction with children }\end{array}$ & 4.41 & .376 & High \\
\hline
\end{tabular}

Table 5 shows that the mathematical averages ranged between 4.17-4.74, Paragraph 19, which states that "the child returns to clean the chapter and maintain the things in it", came in the first place with an average of 4.74. The 
researcher stated that the socialization of the child calls for the need to pay attention to hygiene because cleanliness is one of the distinguishing features of the higher societies, and heavenly religions encourage hygiene so that children can practice their learning and hobbies in a clean, healthy, and disease-free environment. "The reception of each child in the morning is improved by embracing, smiling and welcoming" was the last rank with an average score of 4.17 . This may be due to the fact that the children attend kindergarten in the early morning in the form of tours. They may also attend a group that was received by another teacher and the feeling of some children not wanting to attend kindergarten in the early morning hours in addition to the large number of students in some kindergartens. The arithmetical average of competencies for classroom management and interaction with children as a whole was 4.41 .

\section{Third: Qualifications of Teaching Skills}

Table 6. The arithmetical averages and standard deviations of paragraphs related to the competencies of teaching skills are arranged in descending order by arithmetical averages

\begin{tabular}{|c|c|c|c|c|c|}
\hline Rank & Number & The paragraph & Average & $\begin{array}{c}\text { Standard } \\
\text { Deviation }\end{array}$ & Degree \\
\hline 1 & 23 & $\begin{array}{c}\text { She can create an atmosphere of } \\
\text { love and familiarity }\end{array}$ & 4.70 & .462 & High \\
\hline 2 & 21 & $\begin{array}{l}\text { Create an atmosphere that helps } \\
\text { children learn }\end{array}$ & 4.68 & .468 & High \\
\hline 3 & 22 & $\begin{array}{c}\text { Choose appropriate activities for } \\
\text { children's levels and ages }\end{array}$ & 4.58 & .469 & High \\
\hline 4 & 27 & $\begin{array}{c}\text { Improved time management and } \\
\text { distribution between exercise, rest } \\
\text { and tranquility }\end{array}$ & 4.54 & .589 & High \\
\hline 5 & 30 & $\begin{array}{l}\text { Children participate in selecting } \\
\text { activity topics to ensure that they } \\
\text { interact with them and their attention }\end{array}$ & 4.53 & .501 & High \\
\hline 6 & 24 & $\begin{array}{l}\text { Activities that support the behavioral } \\
\text { values of children }\end{array}$ & 4.50 & .591 & High \\
\hline 7 & 25 & Encourages children to be self-reliant & 4.50 & .659 & High \\
\hline 8 & 29 & $\begin{array}{c}\text { Diversity of educational attitudes in a } \\
\text { way that stimulates children's } \\
\text { motivation to learn }\end{array}$ & 4.45 & .718 & High \\
\hline 9 & 28 & $\begin{array}{l}\text { Positive reinforcement of non- } \\
\text { traditional children's responses is } \\
\text { used and admiration is expressed for } \\
\text { their innovations }\end{array}$ & 4.39 & 1.033 & High \\
\hline 10 & 26 & $\begin{array}{l}\text { Choosing activity topics from real } \\
\text { life so that your child can easily } \\
\text { absorb and interact with them }\end{array}$ & 4.34 & .669 & High \\
\hline & & Teaching skills competencies & 4.50 & .395 & High \\
\hline
\end{tabular}


Table 6 shows that the mathematical averages ranged from 4.26-4.70. Paragraph 23, which states that "you can create an atmosphere of love and familiarity," is ranked first with an average of 4.70. Therefore, the love and the old enrich the psychological life of the child and contribute to the stability and supply of energy. This enables him to live with confidence and helps him to be able to overcome the frustration and despair. Hence, this is what the kindergarten teacher seeks to achieve in children. Paragraph number 26 which states that "Choosing activity topics from real life so that your child can easily absorb and interact with them" came at the last rank with an average of 4.26. In learning different and sophisticated things quickly, one would need to exert more energy in order to simplify everything for the child so he can be able to absorb them. The arithmetic average of teaching skill competencies as a whole was 4.50 .

\section{Fourth: Educational Competencies of the Field of Human Relations}

Table 7. The arithmetical averages and standard deviations of the paragraphs related to the educational competencies of the field of human relations are ranked in a descending order according to the arithmetic averages

\begin{tabular}{|c|c|c|c|c|c|}
\hline Rank & Number & Therage & $\begin{array}{c}\text { Standard } \\
\text { Deviation }\end{array}$ & Degree \\
\hline 1 & 40 & $\begin{array}{c}\text { She listens to the children and make } \\
\text { them feel that they are the focus of } \\
\text { her attention }\end{array}$ & 4.64 & .574 & High \\
\hline 2 & 31 & $\begin{array}{c}\text { Works to strengthen the religious } \\
\text { spirit in children }\end{array}$ & 4.53 & .501 & High \\
\hline 3 & 32 & $\begin{array}{c}\text { She maintains positive relationships } \\
\text { with her colleagues at work }\end{array}$ & 4.42 & .496 & High \\
\hline 4 & 35 & $\begin{array}{c}\text { Benefit from the experiences of the } \\
\text { manager and supervisors }\end{array}$ & 4.40 & .730 & High \\
\hline 5 & 34 & $\begin{array}{c}\text { Working with management and } \\
\text { colleagues in team spirit }\end{array}$ & 4.39 & .659 & High \\
\hline 6 & 39 & $\begin{array}{c}\text { Integrate and interact with children } \\
\text { during the presentation of } \\
\text { experiences }\end{array}$ & 4.39 & .728 & High \\
\hline 7 & 33 & $\begin{array}{c}\text { Interact with the families of the } \\
\text { children in their visits to the } \\
\text { kindergarten }\end{array}$ & 4.38 & .686 & High \\
\hline 8 & 36 & $\begin{array}{c}\text { Benefit from the experiences and } \\
\text { guidance of their colleagues }\end{array}$ & 4.34 & .684 & High \\
\hline 10 & 37 & $\begin{array}{c}\text { Treats children with a sense of } \\
\text { humor and fun }\end{array}$ & 4.34 & .647 & High \\
\hline & $\begin{array}{c}\text { Cooperate with and communicate } \\
\text { with families of children }\end{array}$ & 4.23 & .763 & High \\
\hline field of human relations & Educational competencies for the & 4.41 & .444 & High \\
\hline
\end{tabular}


Table 7 shows that the mathematical averages ranged between 4.234.64. Paragraph 40, which states that "children listen and feel their focus," is ranked first with an average of 4.64. This may be due to playing a key role in the process of learning and communication. This is because it is the art of the highest and the highest responsibilities that falls on the teacher in kindergartens in order to activate the process of dialogue, communication, and learning. Paragraph 37, which reads "cooperate with families of children and communicate with them" ranked last with a mean of 4.23. This may be due to the fact that some families have parents who are employed in different jobs. They had the time and opportunity to visit the kindergarten and communicate with the teacher and also discuss the well being of their child. The mathematical average of educational competencies for human relations as a whole was 4.41 .

\section{Fifth: Vocational Growth Competencies}

Table 8 . The arithmetical averages and standard deviations of paragraphs related to occupational growth competencies are ranked in a descending order by arithmetical averages

\begin{tabular}{|c|c|c|c|c|c|}
\hline Rank & Number & The paragraph & Average & $\begin{array}{c}\text { Standard } \\
\text { Deviation }\end{array}$ & Degree \\
\hline 1 & 41 & $\begin{array}{c}\text { Arabic is fluent in reading and } \\
\text { writing }\end{array}$ & 4.90 & .296 & High \\
\hline 2 & 42 & $\begin{array}{l}\text { Diversity in teaching and learning } \\
\text { methods }\end{array}$ & 4.38 & .579 & High \\
\hline 3 & 50 & $\begin{array}{c}\text { Always wish to innovate in } \\
\text { educational programscolleagues at } \\
\text { work }\end{array}$ & 4.21 & .699 & High \\
\hline 4 & 43 & $\begin{array}{l}\text { Have full knowledge of children's } \\
\text { rights and the ability to defend them }\end{array}$ & 4.18 & .673 & High \\
\hline 5 & 48 & $\begin{array}{l}\text { Use appropriate tools in children's } \\
\text { calendars and characterize their } \\
\text { personalities }\end{array}$ & 4.17 & .811 & High \\
\hline 6 & 44 & $\begin{array}{l}\text { She is keen to keep up with all the } \\
\text { new work with children }\end{array}$ & 4.10 & .811 & High \\
\hline 7 & 49 & $\begin{array}{l}\text { Interact with the families of the } \\
\text { children in their visits to the } \\
\text { kindergarten }\end{array}$ & 4.10 & .551 & High \\
\hline 8 & 46 & $\begin{array}{l}\text { She is keen to update information } \\
\text { about the curriculum in kindergarten }\end{array}$ & 4.06 & .640 & High \\
\hline 9 & 47 & $\begin{array}{l}\text { Cooperate with other institutions } \\
\text { related to child education and } \\
\text { coordinate educational programs for } \\
\text { children's education }\end{array}$ & 4.01 & .713 & High \\
\hline 10 & 45 & $\begin{array}{l}\text { Make sure to take advantage of early } \\
\text { childhood education programs }\end{array}$ & 4.91 & .635 & High \\
\hline & & Professional Growth Competencies & 4.20 & .395 & High \\
\hline
\end{tabular}


Table 8 shows that the mathematical averages ranged between 3.914.90. Paragraph 41, which states that "Arabic proficiency is read and written", came in the first place with a mean average of 4.90. This may be due to the fact that the language of Arabic represents the identity and language of the Arab nation. It is the language of life, and this means it must be mastered and taught to the child correctly and properly. Paragraph 45, which reads "keen to benefit from the programs of early childhood education," ranked last with a mean average of 3.91. This may be due to the fact that the programs for childhood are few (within the researcher's knowledge). Sometimes, they are held at times with the children. This, therefore, makes it difficult to leave them to participate in programs, courses, and seminars that deal with early childhood. The arithmetic average of occupational growth competencies as a whole was 4.20.

- Are there any statistically significant differences at the level of $\alpha \leq 0.05$ based on the exercise of the basic educational competencies of the kindergarten teachers from the point of view of the teachers themselves due to the variable of the training course?

To answer this question, the arithmetic averages and standard deviations of the degree of exercise of the basic educational competencies of the kindergarten teachers were extracted from the teachers' point of view according to the variable of the training course. To illustrate the statistical differences between the mathematical averages, the $\mathrm{T}$ test was used.

Table 9. The statistical averages, standard deviations and T-test of the impact of the training course on the degree of exercise of the basic educational competencies of the kindergarten teachers from the point of view of the teachers themselves

\begin{tabular}{|c|c|c|c|c|c|c|c|}
\hline & $\begin{array}{l}\text { Training } \\
\text { Course }\end{array}$ & Number & Average & $\begin{array}{l}\text { Standard } \\
\text { Deviation }\end{array}$ & $\begin{array}{c}\mathrm{T} \\
\text { value }\end{array}$ & $\begin{array}{l}\text { Degree } \\
\text { of } \\
\text { freedom }\end{array}$ & $\begin{array}{c}\text { Statistical } \\
\text { significance }\end{array}$ \\
\hline \multirow{2}{*}{$\begin{array}{c}\text { Personal } \\
\text { competencies }\end{array}$} & yes & 3 & 4.68 & .349 & \multirow[t]{2}{*}{4.057} & \multirow[t]{2}{*}{123} & \multirow[t]{2}{*}{.000} \\
\hline & No & 2 & 4.40 & .420 & & & \\
\hline \multirow{2}{*}{$\begin{array}{l}\text { Competencies } \\
\text { in the } \\
\text { management of } \\
\text { separation and } \\
\text { interaction with } \\
\text { children }\end{array}$} & yes & 3 & 4.53 & .376 & \multirow[t]{2}{*}{4.189} & \multirow[t]{2}{*}{123} & \multirow[t]{2}{*}{.000} \\
\hline & No & 2 & 4.26 & .324 & & & \\
\hline \multirow{2}{*}{$\begin{array}{l}\text { Teaching skills } \\
\text { competencies }\end{array}$} & yes & 3 & 4.61 & .368 & \multirow[t]{2}{*}{3.987} & \multirow[t]{2}{*}{123} & \\
\hline & No & 2 & 4.34 & .380 & & & \\
\hline \multirow{2}{*}{$\begin{array}{c}\text { Educational } \\
\text { competencies } \\
\text { for the field of } \\
\text { human relations }\end{array}$} & yes & 3 & 4.60 & .410 & \multirow[t]{2}{*}{6.545} & \multirow[t]{2}{*}{123} & \multirow[t]{2}{*}{.000} \\
\hline & No & 2 & 4.14 & .343 & & & \\
\hline \multirow{2}{*}{$\begin{array}{l}\text { Professional } \\
\text { Growth } \\
\text { Competencies }\end{array}$} & yes & 3 & 4.29 & .461 & \multirow[t]{2}{*}{3.171} & \multirow[t]{2}{*}{123} & \multirow[t]{2}{*}{.002} \\
\hline & No & 2 & 4.07 & .223 & & & \\
\hline
\end{tabular}




\begin{tabular}{|c|c|c|c|c|c|c|c|}
\hline \multirow[t]{2}{*}{ Total score } & yes & 3 & 4.54 & .298 & \multirow[t]{2}{*}{5.782} & \multirow[t]{2}{*}{123} & \multirow[t]{2}{*}{.000} \\
\hline & No & 2 & 4.24 & .266 & & & \\
\hline
\end{tabular}

Table 9 shows the existence of statistically significant differences $\alpha \leq 0.05$ due to the impact of the training course in all fields and based on the total scores. The differences were in favor of those who participated in the training course. This may be due to the fact that the training courses enrich the outcome of cognitive teachers and contribute to the development of their skills and awareness of educational developments. Also, this makes it possible for them to be able to identify the latest trends in the field of kindergartens.

- Are there any statistically significant differences at the level of $\alpha \leq 0.05$ based on the level of exercise of the basic educational competencies of kindergarten teachers from the point of view of the teachers themselves due to the variable of experience?

To answer this question, the arithmetical averages and standard deviations of the degree of exercise of the basic educational competencies of the kindergarten teachers were extracted from the teachers' point of view according to the variable of experience. The table below illustrates this.

Table 10. Mathematical averages and standard deviations of the degree of practice of basic educational competencies of kindergarten teachers from the point of view of the

teachers themselves according to the variable of experience

\begin{tabular}{|c|c|c|c|c|}
\hline & Categories & Number & Average & $\begin{array}{c}\text { Standard } \\
\text { Deviation }\end{array}$ \\
\hline \multirow[t]{5}{*}{$\begin{array}{c}\text { Personal } \\
\text { competencies }\end{array}$} & $\begin{array}{c}\text { Less than } 5 \\
\text { years }\end{array}$ & 40 & 4.43 & .473 \\
\hline & $\begin{array}{c}\text { From } 5 \text { to } 10 \\
\text { years }\end{array}$ & 52 & 4.57 & .303 \\
\hline & More than & & & \\
\hline & 10 years & 33 & 4.73 & .398 \\
\hline & The total & 125 & 457 & 403 \\
\hline \multirow{6}{*}{$\begin{array}{l}\text { Competencies in } \\
\text { the management } \\
\text { of separation and } \\
\text { interaction with } \\
\text { children }\end{array}$} & Less than 5 & 40 & 4.31 & .444 \\
\hline & years & & & \\
\hline & From 5 to 10 & 52 & 4.39 & .293 \\
\hline & More than & & & \\
\hline & 10 years & 33 & 4.58 & .372 \\
\hline & The total & 125 & 441 & 379 \\
\hline \multirow{3}{*}{$\begin{array}{l}\text { Teaching skills } \\
\text { competencies }\end{array}$} & Less than 5 & 40 & 4.36 & .347 \\
\hline & years & & & \\
\hline & $\begin{array}{c}\text { From } 5 \text { to } 10 \\
\text { years }\end{array}$ & 52 & 4.44 & .383 \\
\hline
\end{tabular}




\begin{tabular}{|c|c|c|c|c|}
\hline & $\begin{array}{l}\text { More than } \\
10 \text { years }\end{array}$ & 33 & 4.75 & .352 \\
\hline & The total & 125 & 4.50 & .395 \\
\hline \multirow{5}{*}{$\begin{array}{l}\text { Educational } \\
\text { competencies for } \\
\text { the field of } \\
\text { human relations }\end{array}$} & $\begin{array}{c}\text { Less than } 5 \\
\text { years }\end{array}$ & 40 & 4.41 & .401 \\
\hline & $\begin{array}{c}\text { From } 5 \text { to } 10 \\
\text { years }\end{array}$ & 52 & 4.29 & .466 \\
\hline & More than & & & \\
\hline & 10 years & 33 & 4.57 & .413 \\
\hline & The total & 125 & 441 & 444 \\
\hline \multirow{6}{*}{$\begin{array}{l}\text { Professional } \\
\text { Growth } \\
\text { Competencies }\end{array}$} & & 10 & 417 & 218 \\
\hline & years & 40 & 4.17 & .210 \\
\hline & $\begin{array}{c}\text { From } 5 \text { to } 10 \\
\text { years }\end{array}$ & 52 & 4.19 & .304 \\
\hline & More than & & & \\
\hline & 10 years & 33 & 4.25 & .629 \\
\hline & The total & 125 & 400 & 205 \\
\hline \multirow{7}{*}{ Total score } & & 40 & 434 & 310 \\
\hline & $\begin{array}{l}\text { years } \\
\end{array}$ & 40 & 4.54 & .519 \\
\hline & From 5 to 10 & 52 & 4.38 & .292 \\
\hline & More than & & & \\
\hline & 10 years & 33 & 4.58 & .318 \\
\hline & The total & & & 320 \\
\hline & & 125 & 4.42 & .320 \\
\hline
\end{tabular}

Table 10 shows an apparent discrepancy in the arithmetical averages and standard deviations of the degree of exercise of the basic educational competencies of the kindergarten teachers from the point of view of the teachers themselves due to different categories of the variable of experience. To illustrate the significance of the statistical differences between the arithmetic averages, mono-variance analysis was used as shown in Table 11. 
Table 11. Analysis of the mono-variance of the impact of experience on the degree of exercise of the basic educational competencies of the kindergarten teachers from the point of view of the teachers themselves

\begin{tabular}{|c|c|c|c|c|c|c|}
\hline & The source & $\begin{array}{c}\text { Total } \\
\text { squares }\end{array}$ & $\begin{array}{l}\text { Degrees } \\
\text { of } \\
\text { freedo } \\
\text { m }\end{array}$ & $\begin{array}{l}\text { Averag } \\
\text { e } \\
\text { squares }\end{array}$ & $\begin{array}{c}\mathrm{P} \\
\text { value }\end{array}$ & $\begin{array}{c}\text { Statistical } \\
\text { significanc } \\
\text { e }\end{array}$ \\
\hline \multirow{5}{*}{$\begin{array}{c}\text { Personal } \\
\text { competencies }\end{array}$} & \multirow{2}{*}{$\begin{array}{l}\text { Between } \\
\text { groups }\end{array}$} & 1.658 & \begin{tabular}{|l|}
2 \\
\end{tabular} & .829 & \multirow[t]{5}{*}{5.472} & \multirow[t]{5}{*}{.005} \\
\hline & & \multirow{4}{*}{$\begin{array}{c}18.47 \\
8 \\
20.13 \\
6\end{array}$} & 122 & \multirow[t]{4}{*}{.151} & & \\
\hline & \multirow{2}{*}{$\begin{array}{l}\text { Inside the } \\
\text { groups }\end{array}$} & & \multirow[t]{3}{*}{\begin{tabular}{|l|}
124 \\
\end{tabular}} & & & \\
\hline & & & & & & \\
\hline & Total & & & & & \\
\hline \multirow{5}{*}{$\begin{array}{c}\text { Special } \\
\text { competencies } \\
\text { Management } \\
\text { of the } \\
\text { classroom } \\
\text { and } \\
\text { interaction } \\
\text { with children }\end{array}$} & \multirow{2}{*}{$\begin{array}{l}\text { Between } \\
\text { groups }\end{array}$} & 1.295 & 2 & .647 & \multirow[t]{5}{*}{4.795} & \multirow[t]{5}{*}{.010} \\
\hline & & \multirow{4}{*}{$\begin{array}{c}16.47 \\
2 \\
17.76 \\
7 \\
\end{array}$} & 122 & \multirow[t]{4}{*}{.157} & & \\
\hline & Inside the & & \multirow[t]{3}{*}{\begin{tabular}{|l|}
124 \\
\end{tabular}} & & & \\
\hline & groups & & & & & \\
\hline & Total & & & & & \\
\hline \multirow{5}{*}{$\begin{array}{c}\text { Teaching } \\
\text { skills } \\
\text { competencies }\end{array}$} & \multirow{2}{*}{$\begin{array}{c}\text { Between } \\
\text { groups }\end{array}$} & \multirow{5}{*}{$\begin{array}{c}3.162 \\
16.14 \\
6 \\
19.30 \\
8\end{array}$} & \multirow{5}{*}{\begin{tabular}{|c|}
2 \\
122 \\
124 \\
\end{tabular}} & 1.581 & \multirow{5}{*}{$\begin{array}{c}11.94 \\
6\end{array}$} & \multirow[t]{5}{*}{.000} \\
\hline & & & & .132 & & \\
\hline & Inside the & & & & & \\
\hline & groups & & & & & \\
\hline & Total & & & & & \\
\hline \multirow{5}{*}{$\begin{array}{l}\text { Educational } \\
\text { competencies } \\
\text { for the field } \\
\text { of human } \\
\text { relations }\end{array}$} & \multirow{2}{*}{$\begin{array}{l}\text { Between } \\
\text { groups }\end{array}$} & 1.570 & 2 & .785 & \multirow[t]{5}{*}{4.196} & \multirow[t]{5}{*}{.017} \\
\hline & & 22.82 & 122 & .187 & & \\
\hline & \multirow{2}{*}{$\begin{array}{l}\text { Inside the } \\
\text { groups }\end{array}$} & 5 & 124 & & & \\
\hline & & 24.39 & & & & \\
\hline & Total & 5 & & & & \\
\hline \multirow{5}{*}{$\begin{array}{l}\text { Professional } \\
\text { Growth } \\
\text { Competencie } \\
\text { s }\end{array}$} & \multirow{2}{*}{$\begin{array}{c}\text { Between } \\
\text { groups }\end{array}$} & .098 & 2 & .049 & \multirow[t]{5}{*}{.312} & \multirow[t]{5}{*}{.733} \\
\hline & & 19.20 & 122 & .157 & & \\
\hline & Inside the & 2 & 124 & & & \\
\hline & groups & 19.30 & & & & \\
\hline & Total & 1 & & & & \\
\hline Total score & Between & 1.161 & 2 & .580 & 6.133 & .003 \\
\hline & groups & 11.54 & 122 & .095 & & \\
\hline & Inside the & 4 & 124 & & & \\
\hline & groups & 12.70 & & & & \\
\hline & Total & 5 & & & & \\
\hline
\end{tabular}

Table 11 shows statistically significant differences at the level of $\alpha \leq 0.05$ due to experience in all fields and in the tool as a whole except for professional growth competencies. Also, it shows statistical significant differences between statistical averages as shown in Table 12 . 
Table 12. Post-comparisons in a manner that explains the impact of experience on the degree of the exercise of the basic educational competencies of kindergarten teachers from the point of view of the teachers themselves

\begin{tabular}{|c|c|c|c|c|c|}
\hline & Experience & Average & $\begin{array}{c}\text { Less than } 5 \\
\text { years }\end{array}$ & $\begin{array}{c}\text { From } 5 \text { to } \\
10 \text { years }\end{array}$ & $\begin{array}{c}\text { More than } \\
10 \text { years }\end{array}$ \\
\hline \multirow[t]{3}{*}{$\begin{array}{c}\text { Personal } \\
\text { competencies }\end{array}$} & $\begin{array}{l}\text { Less than } \\
5 \text { years }\end{array}$ & 4.43 & & & \\
\hline & $\begin{array}{c}\text { From } 5 \\
\text { to } 10 \\
\text { years }\end{array}$ & 4.57 & 0.15 & & \\
\hline & $\begin{array}{c}\text { More } \\
\text { than } 10 \\
\text { years }\end{array}$ & 4.73 & 0.30 & 0.15 & \\
\hline \multirow{3}{*}{$\begin{array}{l}\text { Competencies } \\
\text { in the } \\
\text { management } \\
\text { of separation } \\
\text { and } \\
\text { interaction } \\
\text { with children }\end{array}$} & $\begin{array}{l}\text { Less than } \\
5 \text { years }\end{array}$ & 4.31 & & & \\
\hline & $\begin{array}{l}\text { From } 5 \\
\text { to } 10\end{array}$ & 4.39 & 0.07 & & \\
\hline & $\begin{array}{c}\text { years } \\
\text { More } \\
\text { than } 10 \\
\text { years }\end{array}$ & 4.58 & $0.26^{*}$ & 0.19 & \\
\hline \multirow{3}{*}{$\begin{array}{c}\text { Teaching } \\
\text { skills } \\
\text { competencies }\end{array}$} & $\begin{array}{l}\text { Less than } \\
5 \text { years }\end{array}$ & 4.36 & 4.44 & & \\
\hline & $\begin{array}{l}\text { From } 5 \\
\text { to } 10\end{array}$ & 4.75 & $0.40 *$ & $0.31 *$ & \\
\hline & $\begin{array}{l}\text { More } \\
\text { than } 10 \\
\text { years }\end{array}$ & 4.41 & & & \\
\hline \multirow{3}{*}{$\begin{array}{l}\text { Educational } \\
\text { competencies } \\
\text { for the field } \\
\text { of human } \\
\text { relations }\end{array}$} & $\begin{array}{l}\text { Less than } \\
5 \text { years }\end{array}$ & 4.41 & & & \\
\hline & $\begin{array}{c}\text { From } 5 \\
\text { to } 10 \\
\text { years }\end{array}$ & 4.29 & 0.12 & & \\
\hline & $\begin{array}{c}\text { More } \\
\text { than } 10 \\
\text { years }\end{array}$ & 4.57 & 0.16 & $0.28 *$ & \\
\hline \multirow[t]{3}{*}{ Total score } & $\begin{array}{l}\text { Less than } \\
5 \text { years }\end{array}$ & 4.34 & & & \\
\hline & $\begin{array}{c}\text { From } 5 \\
\text { to } 10 \\
\text { years }\end{array}$ & 4.38 & $0.04 *$ & & \\
\hline & $\begin{array}{l}\text { More } \\
\text { than } 10 \\
\text { years }\end{array}$ & 4.58 & $0.24 *$ & $0.20 *$ & \\
\hline
\end{tabular}

* Function at the level of significance $\alpha \leq 0.05$. 
Table 12 shows the following:

- There are statistically significant differences between less than 5 years and 10 years and more. The differences for the benefit of 10 years and more in personal competencies, and competencies for the management of separation and interaction with children may be attributed to the more time and experience of dealing with children. This can be seen from the mastery of competencies, especially personal competencies, which are the basis for creating an atmosphere of tranquility and effective classroom interaction.

- There are differences of statistical significance between 10 years and more on the one hand and each of less than 5 years, and 5-10 years on the other hand. The differences came in favor of 5-10 years in the competencies of teaching skills and the overall degree. Thus, this may be due to the fact that the cognitive and skillful outcome of this group is still firmly rooted in memory and it exercises its skills on the ground. This is in addition to the fact that the members of this sample are more numerous than the other categories. - The existence of differences of statistical significance between 10 years and more and from 5-10 years. The differences in favor of 10 years and more educational competencies for the field of human relations may be attributed to the fact that the more experience and the working period of the kindergarten teacher with children whenever they are closer to them, the more they would understand their characteristics. Thus, the requirement is in becoming a mother to them.

4- Are there any statistically significant differences $(\alpha \leq 0.05)$ based on the degree of exercise of the basic educational competencies of the kindergarten teachers from the point of view of the teachers themselves due to the variable of the scientific qualification?

To answer this question, the arithmetical averages and the standard deviations of the degree of exercise of the basic educational competencies of the kindergarten teachers were extracted from the teachers' point of view according to the scientific qualification variable. The table below shows this.

Table 13. Mathematical averages and standard deviations of the degree of exercise of the basic educational competencies of the kindergarten teachers from the point of view of the teachers themselves according to the variable of the scientific qualification 


\begin{tabular}{|c|c|c|c|c|}
\hline & Categories & Number & Average & $\begin{array}{c}\text { Standard } \\
\text { Deviation }\end{array}$ \\
\hline \multirow{4}{*}{$\begin{array}{c}\text { Personal } \\
\text { competencies }\end{array}$} & Diploma & 39 & 4.40 & .327 \\
\hline & Bachelor & 54 & 4.83 & .234 \\
\hline & Higher & 32 & 4.32 & .458 \\
\hline & studies & 125 & 4.57 & .403 \\
\hline \multirow{5}{*}{$\begin{array}{l}\text { Special } \\
\text { competencies } \\
\text { Management of } \\
\text { the classroom } \\
\text { and interaction } \\
\text { with children }\end{array}$} & Diploma & 39 & 4.23 & .367 \\
\hline & Bachelor & 54 & 4.54 & .328 \\
\hline & Higher & 32 & 4.42 & .390 \\
\hline & studies & 125 & 4.41 & .379 \\
\hline & 100tal & & & \\
\hline \multirow{4}{*}{$\begin{array}{l}\text { Teaching skills } \\
\text { competencies }\end{array}$} & Diploma & 39 & 4.53 & .409 \\
\hline & Bachelor & 54 & 4.63 & .291 \\
\hline & Higher & 32 & 4.23 & .407 \\
\hline & Total & 125 & 4.50 & .395 \\
\hline \multirow{4}{*}{$\begin{array}{l}\text { Educational } \\
\text { competencies for } \\
\text { the field of } \\
\text { human relations }\end{array}$} & Diploma & 39 & 4.41 & .369 \\
\hline & Bachelor & 54 & 4.57 & .380 \\
\hline & Higher & 32 & .498 & .498 \\
\hline & $\begin{array}{c}\text { Stuales } \\
\text { Total }\end{array}$ & 125 & .444 & .444 \\
\hline \multirow{4}{*}{$\begin{array}{l}\text { Professional } \\
\text { Growth } \\
\text { Competencies }\end{array}$} & Diploma & & 4.10 & .220 \\
\hline & Bachelor & & 4.31 & .468 \\
\hline & Higher & & 4.13 & .386 \\
\hline & $\begin{array}{c}\text { Studies } \\
\text { Total }\end{array}$ & & 4.20 & .395 \\
\hline \multirow[t]{4}{*}{ Total score } & Diploma & 4.33 & 4.33 & .274 \\
\hline & Bachelor & 4.58 & 4.58 & .237 \\
\hline & Higher & 4.24 & 4.24 & .370 \\
\hline & Total & 4.42 & 4.42 & .320 \\
\hline
\end{tabular}

Table 13 shows an apparent discrepancy in the arithmetical averages and standard deviations of the degree of exercise of the basic educational competencies of the kindergarten teachers from the point of view of the teachers themselves due to the different categories of the qualified variable. To illustrate the significance of the statistical differences between the arithmetic averages, a single analysis of variance was used in Table 14. 
Table 14. Analysis of the single variance of the impact of the scientific qualification based on the degree of the exercise of the basic educational competencies of kindergarten teachers from the point of view of the teachers themselves

\begin{tabular}{|c|c|c|c|c|c|c|}
\hline & The source & $\begin{array}{c}\text { Total } \\
\text { squares }\end{array}$ & $\begin{array}{l}\text { Degrees } \\
\text { of } \\
\text { freedo } \\
\text { m }\end{array}$ & $\begin{array}{l}\text { Averag } \\
\text { e } \\
\text { squares }\end{array}$ & $\begin{array}{c}\mathrm{P} \\
\text { value }\end{array}$ & $\begin{array}{c}\text { Statistical } \\
\text { significanc } \\
\mathrm{e}\end{array}$ \\
\hline \multirow{5}{*}{$\begin{array}{c}\text { Personal } \\
\text { competencies }\end{array}$} & \multirow{2}{*}{$\begin{array}{l}\text { Between } \\
\text { groups }\end{array}$} & \multirow{3}{*}{$\begin{array}{c}6.653 \\
13.48 \\
2\end{array}$} & \multirow{5}{*}{\begin{tabular}{|c|}
2 \\
122 \\
124 \\
\end{tabular}} & \multirow{5}{*}{\begin{tabular}{|c|}
3.327 \\
.111 \\
\end{tabular}} & \multirow{5}{*}{$\begin{array}{c}30.10 \\
2\end{array}$} & \multirow[t]{5}{*}{.000} \\
\hline & & & & & & \\
\hline & Inside the & & & & & \\
\hline & groups & \multirow{2}{*}{$\begin{array}{c}20.13 \\
6\end{array}$} & & & & \\
\hline & Total & & & & & \\
\hline \multirow{5}{*}{$\begin{array}{c}\text { Special } \\
\text { competencies } \\
\text { Management } \\
\text { of the } \\
\text { classroom } \\
\text { and } \\
\text { interaction } \\
\text { with children }\end{array}$} & \multirow{2}{*}{$\begin{array}{l}\text { Between } \\
\text { groups }\end{array}$} & \multirow{3}{*}{$\begin{array}{c}2.228 \\
15.53 \\
9 \\
\end{array}$} & 2 & 1.114 & \multirow[t]{5}{*}{8.748} & \multirow[t]{5}{*}{.000} \\
\hline & & & 122 & .127 & & \\
\hline & \multirow{2}{*}{$\begin{array}{l}\text { Inside the } \\
\text { groups }\end{array}$} & & 124 & & & \\
\hline & & \multirow{2}{*}{$\begin{array}{c}17.76 \\
7 \\
\end{array}$} & & & & \\
\hline & Total & & & & & \\
\hline \multirow{5}{*}{$\begin{array}{c}\text { Teaching } \\
\text { skills } \\
\text { competencies }\end{array}$} & \multirow{2}{*}{$\begin{array}{c}\text { Between } \\
\text { groups }\end{array}$} & \multirow{5}{*}{$\begin{array}{c}3.328 \\
15.98 \\
0 \\
19.30 \\
8\end{array}$} & 2 & 1.664 & \multirow{5}{*}{$\begin{array}{c}12.70 \\
3\end{array}$} & \multirow[t]{5}{*}{.000} \\
\hline & & & 122 & .131 & & \\
\hline & \multirow{2}{*}{$\begin{array}{l}\text { Inside the } \\
\text { groups }\end{array}$} & & 124 & & & \\
\hline & & & & & & \\
\hline & Total & & & & & \\
\hline \multirow{5}{*}{$\begin{array}{c}\text { Educational } \\
\text { competencies } \\
\text { for the field } \\
\text { of human } \\
\text { relations }\end{array}$} & \multirow{2}{*}{$\begin{array}{c}\text { Between } \\
\text { groups }\end{array}$} & 3.986 & 2 & 1.993 & \multirow{5}{*}{$\begin{array}{c}11.91 \\
5\end{array}$} & \multirow[t]{5}{*}{.000} \\
\hline & & \multirow{4}{*}{$\begin{array}{c}20.40 \\
8 \\
24.39 \\
5\end{array}$} & 122 & .167 & & \\
\hline & \multirow{2}{*}{$\begin{array}{l}\text { Inside the } \\
\text { groups }\end{array}$} & & 124 & & & \\
\hline & & & & & & \\
\hline & Total & & & & & \\
\hline \multirow{5}{*}{$\begin{array}{l}\text { Professional } \\
\text { Growth } \\
\text { Competencie } \\
\text { s }\end{array}$} & \multirow{2}{*}{$\begin{array}{l}\text { Between } \\
\text { groups }\end{array}$} & .098 & 2 & .623 & \multirow[t]{5}{*}{4.211} & .017 \\
\hline & & 19.20 & 122 & .148 & & \\
\hline & Inside the & 2 & 124 & & & \\
\hline & groups & 19.30 & & & & \\
\hline & Total & 1 & & & & \\
\hline Total score & Between & 1.246 & 2 & 1.306 & 15.79 & .000 \\
\hline & groups & 18.05 & 122 & .083 & 1 & \\
\hline & Inside the & 4 & 124 & & & \\
\hline & groups & 19.30 & & & & \\
\hline & Total & 1 & & & & \\
\hline
\end{tabular}

Table 14 shows that there are statistically significant differences at the level of $\alpha \leq 0.05$ attributed to the scientific qualification in all fields and in the tool as a whole. In order to show statistically significant differences between the arithmetic mean, the post comparisons were used in the same way as shown in Table 15. 
Table 15. Comparative comparisons in a way that explains the effect of the academic qualification based on the degree of the exercise of the basic educational competencies of kindergarten teachers from the point of view of the teachers themselves

\begin{tabular}{|c|c|c|c|c|c|}
\hline & Categories & Average & Diploma & Bachelor & $\begin{array}{l}\text { Higher } \\
\text { study }\end{array}$ \\
\hline \multirow{3}{*}{$\begin{array}{c}\text { Personal } \\
\text { competencies }\end{array}$} & Diploma & 4.40 & & & \\
\hline & Bachelor & 4.83 & .43 & & \\
\hline & $\begin{array}{l}\text { Higher } \\
\text { studies }\end{array}$ & 4.32 & .08 & 50 & \\
\hline \multirow{4}{*}{$\begin{array}{c}\text { Special } \\
\text { competencies } \\
\text { Management } \\
\text { of the } \\
\text { classroom } \\
\text { and } \\
\text { interaction } \\
\text { with children }\end{array}$} & Diploma & 4.23 & & & \\
\hline & Bachelor & 4.54 & .31 & & \\
\hline & $\begin{array}{l}\text { Higher } \\
\text { studies }\end{array}$ & 4.42 & .18 & .13 & \\
\hline & & & & & \\
\hline \multirow{3}{*}{$\begin{array}{c}\text { Teaching } \\
\text { skills } \\
\text { competencies }\end{array}$} & Diploma & 4.53 & & & \\
\hline & Bachelor & 4.63 & .10 & & \\
\hline & $\begin{array}{l}\text { Higher } \\
\text { studies }\end{array}$ & 4.23 & $030 *$ & $4.23 *$ & \\
\hline \multirow{3}{*}{$\begin{array}{l}\text { Educational } \\
\text { competencies } \\
\text { for the field } \\
\text { of human } \\
\text { relations }\end{array}$} & Diploma & 4.41 & & & \\
\hline & Bachelor & 4.57 & .16 & & \\
\hline & $\begin{array}{l}\text { Higher } \\
\text { studies }\end{array}$ & 4.12 & $.29 *$ & $45^{*}$ & \\
\hline \multirow{3}{*}{$\begin{array}{l}\text { Professional } \\
\text { Growth } \\
\text { Competencies }\end{array}$} & Diploma & 4.10 & 4.10 & & \\
\hline & Bachelor & 4.31 & $.21 *$ & & \\
\hline & $\begin{array}{l}\text { Higher } \\
\text { studies }\end{array}$ & 4.13 & 4.13 & & \\
\hline \multirow[t]{3}{*}{ Total score } & Diploma & 4.33 & & & \\
\hline & Bachelor & 4.58 & $24 *$ & & \\
\hline & $\begin{array}{l}\text { Higher } \\
\text { studies }\end{array}$ & 4.24 & .09 & $.33 *$ & \\
\hline
\end{tabular}

* Function at the level of significance $(\alpha \leq 0.05)$.

Table 15 shows the following:

- There were statistically significant differences between Bachelor and Diploma on one hand and postgraduate studies on the other hand. The differences were in favor of Bachelor of personal competencies and the total degree. This may be due to the fact that the teachers of the bachelor degree dealt with the specialization courses of kindergartens in a specialized and intensive manner. This is based on the practical training chapter in the field as the number of members of the bachelor degree sample is the most. 
- There are differences of statistical significance $(\alpha \leq 0.05)$ between Bachelor and Diploma and the differences came in favor of a Bachelor in the competencies of the Department of separation and interaction with children and the competencies of professional growth. This may be due to the fact that the field training separation made the grade teacher more proficient in skills and competencies than the diploma category.

- The existence of differences of statistical significance $(\alpha \leq 0.05)$ between postgraduate studies on the one hand and each diploma and bachelor on the other hand. Thus, the differences came in favor of each diploma. Also, a bachelor in the educational competencies of the field of human relations and the competencies of teaching skills may be due to the fact that the parameters of the diploma and bachelor degree were apprentices. The process of learning is motivated and they have a sense of motherhood towards children.

\section{Recommendations}

In light of the results of the current study, the researcher recommends the following:

- Holding training courses that contribute to increasing the efficiency and skills of kindergarten teachers.

- Conducting similar studies on samples of other grades.

\section{References:}

\section{Arabic References}

1. Abu Harb Yahya (2005). Teaching competencies for pre-school teachers in the light of the development of curriculum models for the 21 st century, Conference of Children and Youth in the Cities of the Middle East and North Africa, held in Dubai, United Arab Emirates, 17-19 April 2005, pp. 52-87.

2. Hariri Rafida (2002). Kindergarten, Sikan Library, Amman Jordan. Sulaimani, Al Arabi, (2006). Competencies in Education for a Comprehensive Approach, Al-Najah Al-Jadida Press, Casablanca Morocco.

3. Holly Abeer \& Jawhar Salwa (2004). The Effectiveness of Using a Suggested Strategy in the Development of Cognitive Aspects in the Children of Riyadh A Pilot Study, Future Journal of Arab Education, Issue 39, Cairo University, Egypt.

4. Kamel Said (2000). The foundations of child education between theory and practice, Dar al-Maarifa al-Jami'a, Alexandria Egypt.

5. Karrar Mohammed (2000). Kindergarten Styles and Skills, Al Falah Printing and Publishing Library, Kuwait Kuwait. 
6. Karam Ibrahim (2002). The extent of mastery of the social materials in the schools of education in Kuwait for teaching competencies, Journal of Psychological and Educational Sciences, vol. 3, no. 4, University of Bahrain.

7. Murtaza Salwa (2001). Social Status of the Kindergarten Teacher, Journal of Arab Childhood, Kuwait Society for the Advancement of Arab Children, vol. 8, pp. 29-51.

8. Mardan Necmettin, Cherif Nadia, \& Abdel-Al Samira (2004). Arab Educational Reference for Kindergarten Programs, Tunisia, Arab Organization for Education, Culture and Science, Department of Education Programs.

9. Mr. Hana (2013). Professional competencies required for the role of kindergarten teachers in the light of quality standards, unpublished master thesis, Banha University Egypt.

10. Shibani Helmi (2001). Problems of Kindergartens in the Republic of Yemen from the point of view of the nannies, an unpublished letter of Majister, University of Baghdad, Iraq The Decorated, Solomon; The Crow, Hisham (2005). The basic competencies of kindergarten teachers from the perspective of the directors of Riyadh, the second educational conference, the Palestinian child between the challenges of reality and the aspirations of the future, held from 22 to 23 November 2005, Faculty of Education, Islamic University. In terms of quality of pre-primary education (kindergarten stage), Tunisia.

\section{Foreign References}

11. Al-Hooli Abeer (2001). Kuwaiti Kindergarten Teachers' Attitudes and Content Knowledge of Teaching Science and Using Children's Literature for Science Instruction, (Doctoral dissertation, University of Virginia), Dissertation Abstracts International.

12. Holi Abir, Jawhar Salwa, \& Al-Qallaf Nabil (2007). The personal and performance competencies of kindergarten teachers in the light of the developed method, Gulf Message, No. 105, 59 - 121.

13. Kemp (2000). A Comparison Of Achievement Gains Of Kindergarten Teachers In Competency Based Education And Traditional Education, Journal Of Education Research, Vol (78), No (22), P 256-280.

14. Kiesner Eileen (2008). Improving Teachers Education Field Experience Recourses For Education, ERIC, ED, (47686).

15. Selven Eileen (2003). Basic Performance Competency \& Measure If Teachers Doing It In Kindergarten, Recourses For Education, ERIC, ED, (47686).

16. Quebec Education Program - Preschool Education, (2002).website:

17. http://www.meq.gouv.qc.ca//virage/publications/prog-form- 
preschool-a.htm. Accessed 4/5/2002.

18. Yassin Nawal (2003). Evaluation of the Skills of Kindergarten Teachers in the Holy Capital, Um Al-Qura University Journal of Educational and Social Sciences, Vol. 1, No. (15), pp. 115-146. 